\title{
ULTRASTRUCTURE OF SULPHIDOGENIC BIOFILMS RICH IN SULPHATE-REDUCING BACTERIA CAUSING CORROSION IN THE OFFSHORE OIL EXTRACTION PLATFORMS OFF BRAZIL'S ATLANTIC COAST
}

\author{
CLAÚdiA M. L. M. COUTINHO,* FÁTIMA C. MAGALHÃES, ${ }^{1}$ \\ AND TANIA C. ARAÚJO-JORGE \\ Laboratório de Biologia Celular, Depto. Ultraestrutura e Biologia Celular, \\ Instituto Oswaldo Cruz, Fiocruz, Rio de Janeiro RJ21045-900, Brasil \\ ${ }^{1}$ Petróleo Brasileiro S.A., CENPES, PETROBRAS, Cidade Universitária, \\ Rio de Janeiro RJ21949-900, Brasil
}

(Received June 18, 1993; Accepted June 13, 1994)

\begin{abstract}
Microorganisms, especially sulphate-reducing bacteria (SRB), have long been implicated in metal corrosion in the petroleum industry. SRB can appear in planktonic or adherent forms, interacting with surfaces to produce thick, consortial biofilms. We carried out an ultrastructural investigation of biofilms and planktonic bacteria obtained from samplers on offshore platforms operated in southeast Brazil. A great variety of Gram-negative bacteria were observed. The surface coat and extracellular matrix of these cells stained strongly with ruthenium red, indicating their anionic character. Sessile bacteria were found to be enmeshed in an extensive extracellular matrix. The inner ultrastructure of sessile bacteria was characterized by vacuoles, inclusions and internal membranes. ESI analysis revealed the presence of corrosion products associated with the surface coat of these bacteria.
\end{abstract}

Biocorrosion is the process whereby microorganisms cause degradation of metallic surfaces. These microorganisms can either be indirectly responsible for creating a corrosive environment or they can take part directly in electrochemical reactions occurring on the surface of the metal $(1,13)$. Biocorrosion has a considerable economic impact on the petroleum industry, inflicting especially heavy damage on the water injection systems used in secondary oil production (12). In these systems, marine water is taken from sites close to the platform, deaerated to

* Address reprint requests to: Dr. Cláudia M. L. M. Coutinho, Laboratório de Biologia Celular, Depto. Ultraestrutura e Biologia Celular, Instituto Oswaldo Cruz, Fiocruz, Av. Brasil 4365, Rio de Janeiro RJ21045-900, Brasil. 
prevent oxygen corrosion, treated and then injected into the oil well to maintain the reservoir's pressure. The resulting environment is favorable to bacterial growth, and especially favorable to the proliferation of sulphate-reducing bacteria (SRB), in that it offers conditions for anaerobiosis in the presence of sulphate and nutrients, as well as an adequate temperature (ranging from 29 to $35^{\circ} \mathrm{C}$ ) and a metallic substrate for bacterial adhesion (the pipeline alloy).

SRB constitute a heterogenous group of taxonomically and morphologically diverse genera and species, that are related in terms of ecology and physiology (11, 23). In keeping with the universal strategy of microorganisms to attach to substrates and to grow in consortia with a variety of species, SRB adhere to inert surfaces and develop biofilms $(1,4,5)$. These biofilms mediate the interaction between metal surfaces and the environment in biodeterioration processes such as corrosion (10), as well as in several biotechnological processes applied to materials recovery and handling (26). Bacterial population living within biofilms also produce planktonic free-swimming cells, whose survival chances are lower than those of their sessile counterparts $(6,7)$.

The corrosion associated with microbial growth on metal surfaces, and in particular with SRB growth, constitutes the most significant problem encountered in offshore injection systems in Brazil. Data on the community structure of bacteria colonies involved in biocorrosion processes off Brazil's coast are scarce. Since these structures may well differ from those found in the marine environments commonly studied by North American and European research groups, there is a clear need for investigations focused on Brazil. Our study aimed to characterize certain ultrastructural aspects of SRB-rich biofilms, using transmission electron microscopy (TEM) and scanning electron microscopy (SEM). Planktonic and sessile bacteria were both studied, following biofilm formation over metal coupons in situ (in samples installed in the water injection systems of offshore platforms) and in vitro (under a variety of laboratory culture conditions). A previous study of the dynamics of corrosive biofilm formation in the laboratory was published elsewhere (8).

\section{MATERIALS AND METHODS}

Bacteria. To collect field bacteria, Robbins Device samplers (18) were installed for 10 months in the water injection wells of two offshore oil platforms (PNA1 and PNA2) operated by PETROBRAS presenting important corrosion problems off the coast of Campos, in the state of Rio de Janeiro, Brazil. The samplers were applied in a zone near the injection site of the oil well, where suitable temperatures for SRB growth $\left(29-35^{\circ} \mathrm{C}\right)$ as well as high sulphate levels and anaerobic environment conditions are found, especially favoring SRB development, despite the presence of other non sulphur-reducing anaerobes. In the offshore platform, the samplers were analyzed for: (a) enumeration of sessile facultative heterotrophic bacteria by the plating method in a designed medium (3) giving 
undetectable numbers of colony forming units $/ \mathrm{cm}^{2}$; (b) enumeration of sessile anaerobes using the Most Probable Number (MPN) method as described by Bergey et al. (3) and Postgate (23) giving $2.6 \times 10^{6}$ anaerobes $/ \mathrm{cm}^{2}$; (c) sessile SRB enumeration using the method of MPN as described by Postgate (23), giving $3.6 \times$ $10^{5}$ bacteria $/ \mathrm{cm}^{2}$. Samplers were also monitored in the platform for sulphide $\left(\mathrm{H}_{2} \mathrm{~S}\right)$ evolution under acid reaction, yielding $136.6 \mu \mathrm{g} \mathrm{H}_{2} \mathrm{~S} / \mathrm{cm}^{2}$. Devices installed in the wells were also periodically monitored for the type and rate of corrosion, as well as the nature of corrosion products (data not shown). The main type of corrosion observed was pitting, that is characteristic of the action of the sulphate-reducers, with pits being open and filled with soft black corrosion products in the form of iron sulphides (12). Some sampler coupons were immersed in fixative solution in the field, directly after removal from the platform, while others were transported to the laboratory immersed in a nitrogen-purged reduced saline solution (composition in $\mathrm{g} / l$ : sodium thioglycolate 0.124 , ascorbic acid 0.1 , resazurin 0.001 , diluted in synthetic marine water: $\mathrm{NaCl} 24.53, \mathrm{MgCl}_{2} 5.2, \mathrm{Na}_{2} \mathrm{SO}_{4} 4.09, \mathrm{CaCl}_{2} 1.16, \mathrm{KCl}$ $0.695, \mathrm{NaHCO}_{3} 0.201, \mathrm{H}_{3} \mathrm{BO}_{3} 0.027, \mathrm{SrCl}_{2} 0.025$, and $\mathrm{NaF} 0.03$ ).

Bacterial culture. We used Postgate media (23) to culture the biomass obtained from the vortexing or scraping of adherent biofilm from field samplers to enrich the cultures in SRB so that biofilms prepared experimentally would be representative of the natural field biofilms and enriched in the bacteria involved in biocorrosion. The suspension of bacteria was inoculated at $0.5 \%(\mathrm{v} / \mathrm{v})$ in a semi-solid modified Postgate $\mathrm{E}$ medium (23), designed to improve SRB growth (composition in $\mathrm{g} / l: \mathrm{KH}_{2} \mathrm{PO}_{4} 0.5, \mathrm{NH}_{4} \mathrm{Cl}$ 1.0, $\mathrm{Na}_{2} \mathrm{SO}_{4}$ 1.0, $\mathrm{CaCl}_{2} \cdot 6 \mathrm{H}_{2} \mathrm{O}$ 1.0, $\mathrm{MgCl}_{2}$. $7 \mathrm{H}_{2} \mathrm{O} 1.83$, yeast extract 1.0 , ascorbic acid $0.1, \mathrm{FeSO}_{4} \cdot 7 \mathrm{H}_{2} \mathrm{O} 0.5$, agar 1.9 , sodium thioglycolate 0.124 , sodium lactate 3.5 , and resazurine 0.001 ) or in semi-solid modified Postgate $\mathrm{C}$ medium (composition in $\mathrm{g} / l: \mathrm{KH}_{2} \mathrm{PO}_{4} 0.5, \mathrm{NH}_{4} \mathrm{Cl} 1.0, \mathrm{Na}_{2} \mathrm{SO}_{4}$ 4.5, $\mathrm{CaCl}_{2} \cdot 6 \mathrm{H}_{2} \mathrm{O} 0.06, \mathrm{MgSO}_{4} \cdot 7 \mathrm{H}_{2} \mathrm{O} 0.06$, yeast extract $1.0, \mathrm{FeSO}_{4} \cdot 7 \mathrm{H}_{2} \mathrm{O} 0.004$, agar 1.9, sodium citrate $\cdot 2 \mathrm{H}_{2} \mathrm{O} 0.3$, sodium lactate 3.5 , and resazurine 0.001 ), both diluted in synthetic marine water, at $\mathrm{pH} 7.6^{-7.8}$ in a water bath adjusted to $30^{\circ} \mathrm{C}$. This mixed culture of bacteria was weekly passed and periodically analyzed by: (a) SRB enumeration through MPN (23) and (b) $\mathrm{H}_{2} \mathrm{~S}$ production determined spectrophotometrically using a technique based on alkaline precipitation in cadmium sulphate as previously described (14). Bacterial growth was also indicated by presence of black precipitates of $\mathrm{FeS}$ and turbidity. Cultures were maintained in anaerobiosis by purging with nitrogen. Test coupons consisting of rectangular plates $(3.5 \times 1.5 \mathrm{~cm})$ of 1,020 carbon-steel (with the same composition as the material at the original site of bacterial fouling on the platform) were cleaned by sand-blasting, rinsed in ether and distilled water, and autoclaved prior to being hung on glass supports and immersed in medium inside an anaerobic reactor.

Conventional transmission electron microscopy (TEM). After seven days of incubation with bacteria, the test coupons were removed and processed for TEM. They were fixed for $3 \mathrm{~h}$ in $5 \%$ glutaraldehyde in $0.1 \mathrm{M}$ sodium cacodylate buffer prepared with sea water, then washed in the same buffer, post-fixed in $1 \% \mathrm{OsO}_{4}$ at 
$4^{\circ} \mathrm{C}$ for $1.5 \mathrm{~h}$, desalinated, dehydrated in acetone, and embedded in Epon.

For the detection of carbohydrates, ruthenium red (RR), a cationic electrodense marker for acid polysaccharides (17), was added throughout at a concentration of $0.14 \%$ during fixation and $0.07 \%$ during washing. In some experiments, $2 \%$ tannic acid was associated to glutaraldehyde in order to detect basic proteins (27). Thin sections were stained with uranyl acetate and lead citrate and examined in a Zeiss EM-10B transmission electron microscope.

Examination of intact cells was carried out using the negative staining procedure. Cell suspensions were spread on 300-mesh copper grids (carbon-stabilized and covered with parlodion film), which were incubated in $4 \%$ phosphotungstic acid for $3 \mathrm{~min}$.

Electronic spectroscopic imaging. Ultrathin sections were examined unstained in a Zeiss EM 902 transmission electron microscope equipped with a prism-mirrorprism type electron imaging spectrometer operated at an acceleration voltage of 80 $\mathrm{kV}$. The width of the spectrometer slit was set at $\Delta E=20 \mathrm{eV}$ throughout. For inelastic imaging, the specimen grids were scanned to find regions of interest containing iron $(\mathrm{Fe})$ and sulphur $(\mathrm{S})$, with enhanced images generated, respectively, at 708 and $165 \mathrm{eV}$ energy loss.

Scanning electron microscopy (SEM). For SEM test coupons were fixed as for TEM, washed and dehydrated in acetone. The samplers were then dried by injection of $\mathrm{CO}_{2}$ in a critical point drying apparatus (CPD-030 Balzers), coated with gold in a sputter coater (SCD-040 Balzers) for $90 \mathrm{~s}$ at $30 \mathrm{~mA}$, resulting in a 15 $\mathrm{nm}$ thick gold layer, and analyzed in a JEOL JXA-840A SEM.

\section{RESULTS}

\section{Biofilms}

SEM (Fig. 1a) and TEM (Fig. 1b) revealed the bacterial organization of biofilms that had formed either in culture over metallic substrates in the laboratory (Fig. 1a) or on test surfaces installed in the PNA1 platform (Fig. 1b). In experiments involving SEM, extensive sections of the extracellular matrix were often found to have collapsed (Fig. 1a, arrowheads), as a direct consequence of the dehydration process required for electron microscopy. Within the microcolonies, cells displayed a wide variety of morphological types, with a predominance of the rod-like morphotype (Fig. 1a). Biofilms were observed to be composed of bacteria organized in adherent microcolonies and enmeshed within an extensive extracellular matrix. The latter proved to be anionic in character, reacting strongly with the cationic compound ruthenium red (Fig. 1b, asterisk).

\section{Morphological diversity}

Different morphotypes of Gram-negative cells (see below) were found among sessile and planktonic bacteria processed from laboratory cultures or directly from the field. The types most commonly observed were, in decreasing order: small and 


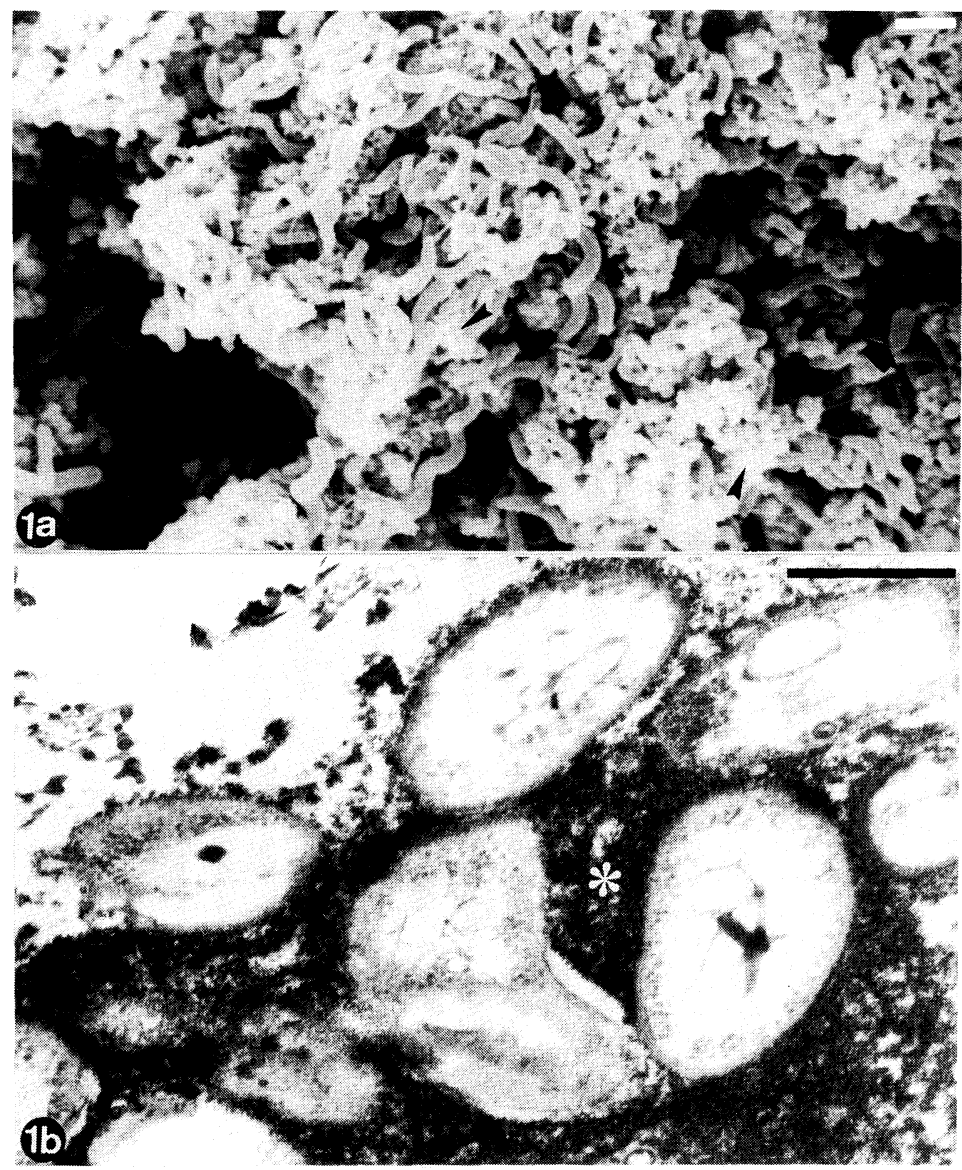

Fig. 1. (a) SEM image of corrosive biofilm rich in SRB on metallic coupons formed by bacteria collected from PNA1, after 7 days of incubation in Postgate C medium.

Note the high concentration and diverse morphology of the bacteria associated with the extracellular polysaccharide matrix (arrowheads). The latter partially collapsed as a result of SEM treatment. The bar indicates $0.3 \mu \mathrm{m}$.

(b) TEM analysis of biofilm showing a bacterial colony obtained by scraping material off field coupons that had been inserted into the pipelines of a marine injection system on an offshore petroleum platform (PNA1). The cells were treated with ruthenium red, which strongly stained the abundant extracellular material (asterisk) surrounding many bacteria. The bar indicates $0.3 \mu \mathrm{m}$.

large rods (Fig. 2a-f); vibrios (Fig. 2a, large arrows); filaments (Fig. 3a, b, thin arrows); spirals (Fig. 3b, c, large arrows, and Fig. 3d,e); ovals (Fig. 1a, large arrow); and, finally, rounded cells (Fig. 3f, g), which were frequently found to have gathered into "bunches." A visible flagellum was observed in certain rod- (Figs. 2e 


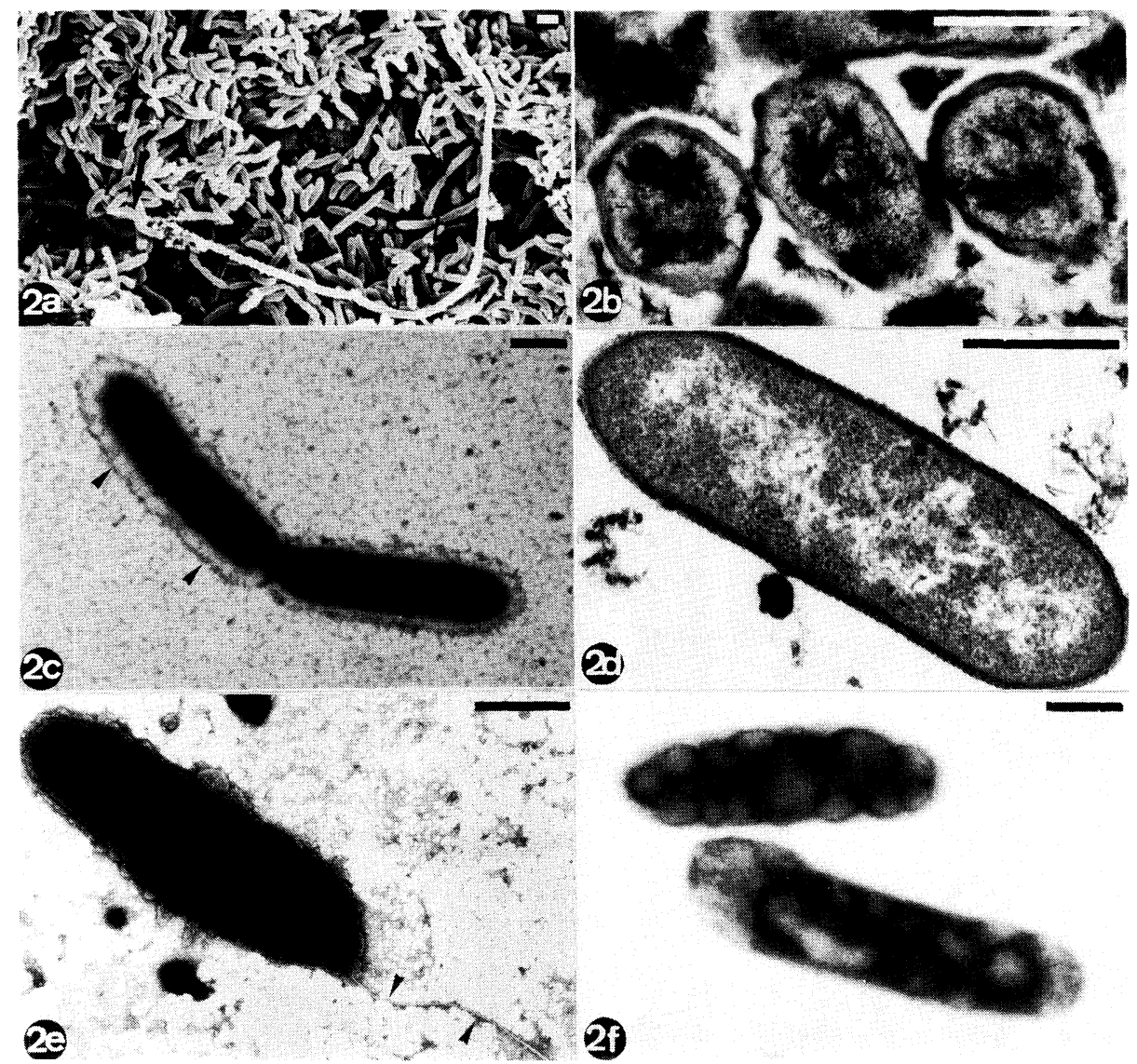

Fig. 2. Sessile (a,b, d,e) and planktonic (c,f) bacteria, seen as large and small rods, originating from PNA1 and cultured in Postgate E (b,c,e,f) and C (a,d), analysed by SEM (a) and TEM (b-f).

The images reveal the internal ultrastructural diversity of these cells (b, $d, f)$, and their tendency to be paired ( $a$, thin arrows, and $c$ ) and to form chains (a, arrowheads). $c$ and e show bacteria submitted to negative staining, revealing a flagellum (e, arrowheads), and an S layer (c, arrowheads). The bars indicate $0.3 \mu \mathrm{m}$.

and 5b, arrowheads) and spiral-shaped bacteria (Fig. 3d, e, arrowheads). Diverse cell types were frequently found together, randomly distributed, but the filamentous and spirillar forms were more often observed in coupons that had been first colonized by rod- and vibrio-shaped bacteria ( 8 and data not shown). Paired rods (maybe representing dividing cells) were frequently seen among planktonic bacteria (Fig. 2c), and were also observed in biofilms (Fig. 2a, thin arrows). They exhibited a peculiar coordinated movement under phase contrast light microscopy. Small or large rods were occasionally observed linked together in chains (Fig. 2a, arrowheads). 


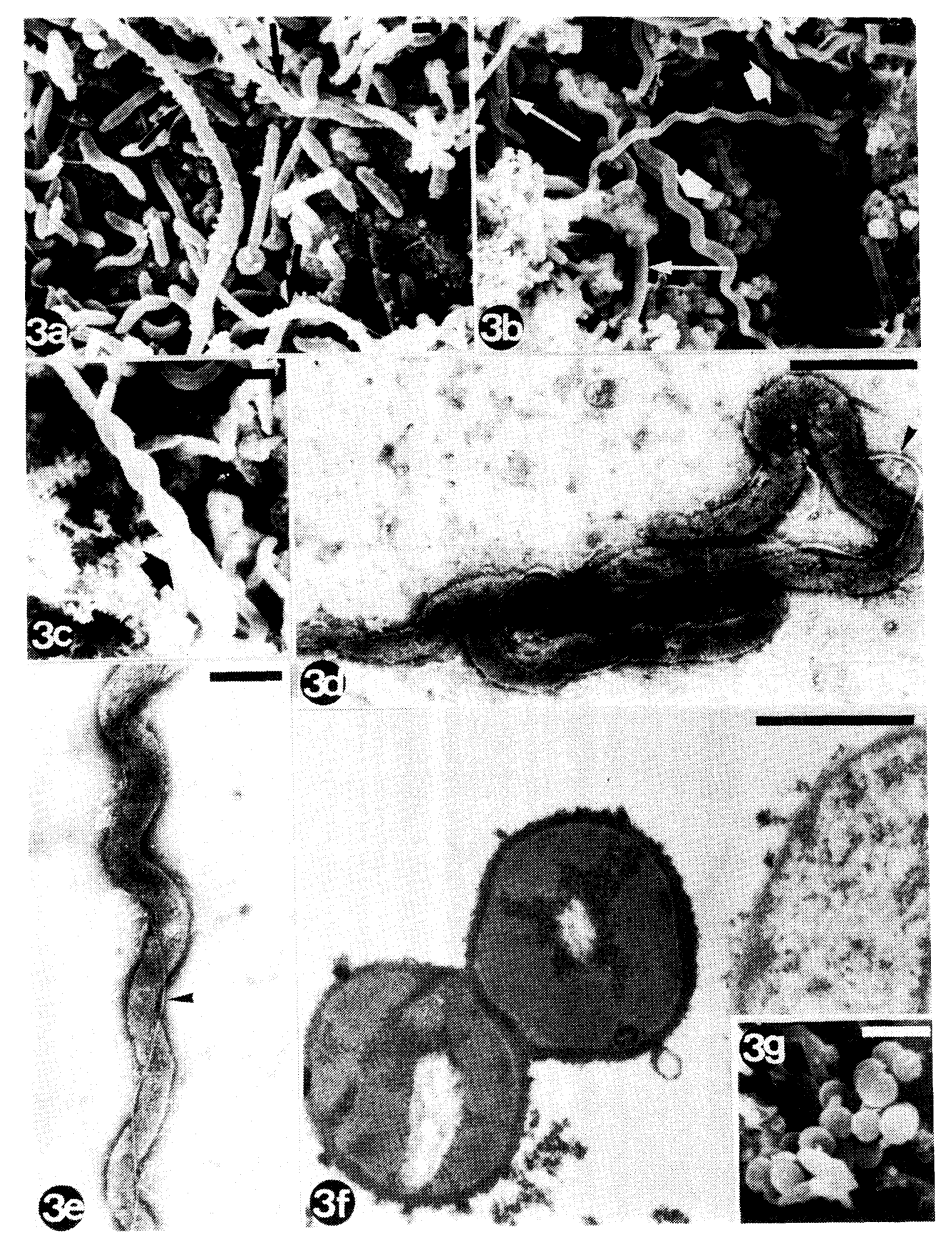

Fig. 3. Filamentous (thin arrows) and spirillar (large arrows) sessile bacteria, originating from PNA1 and cultured in Postgate $\mathrm{C}(\mathrm{a}-\mathrm{e})$ medium.

Negative staining followed by TEM revealed spirillar bacteria with a single flagellum ( $\mathrm{d}$ and $\mathrm{e}$, arrowheads) running along the whole length of the cell body. $\mathrm{f}$ and g, obtained by TEM and SEM, respectively, show cocci collected from PNA1 and cultured over test coupons in Postgate $\mathrm{C}$ medium. The bars indicate $0.3 \mu \mathrm{m}$.

\section{Cell envelope}

The cell envelope (Fig. 4a, b) of these bacteria exhibited the following principal features: an outer membrane (arrowhead), a plasma membrane (arrow) and, occupying the periplasmic space which is clearly visible in between the so-called dense layer (i.e. peptidoglycan layer, asterisk). These three features were found, respectively, to measure approximately $5 \mathrm{~nm}, 5 \mathrm{~nm}$ and $16 \mathrm{~nm}$. The outer membrane exhibited an unit membrane structure similar to that of the plasma membrane, and was observed to have an S layer attached to its outer surface (Fig. 4a, 


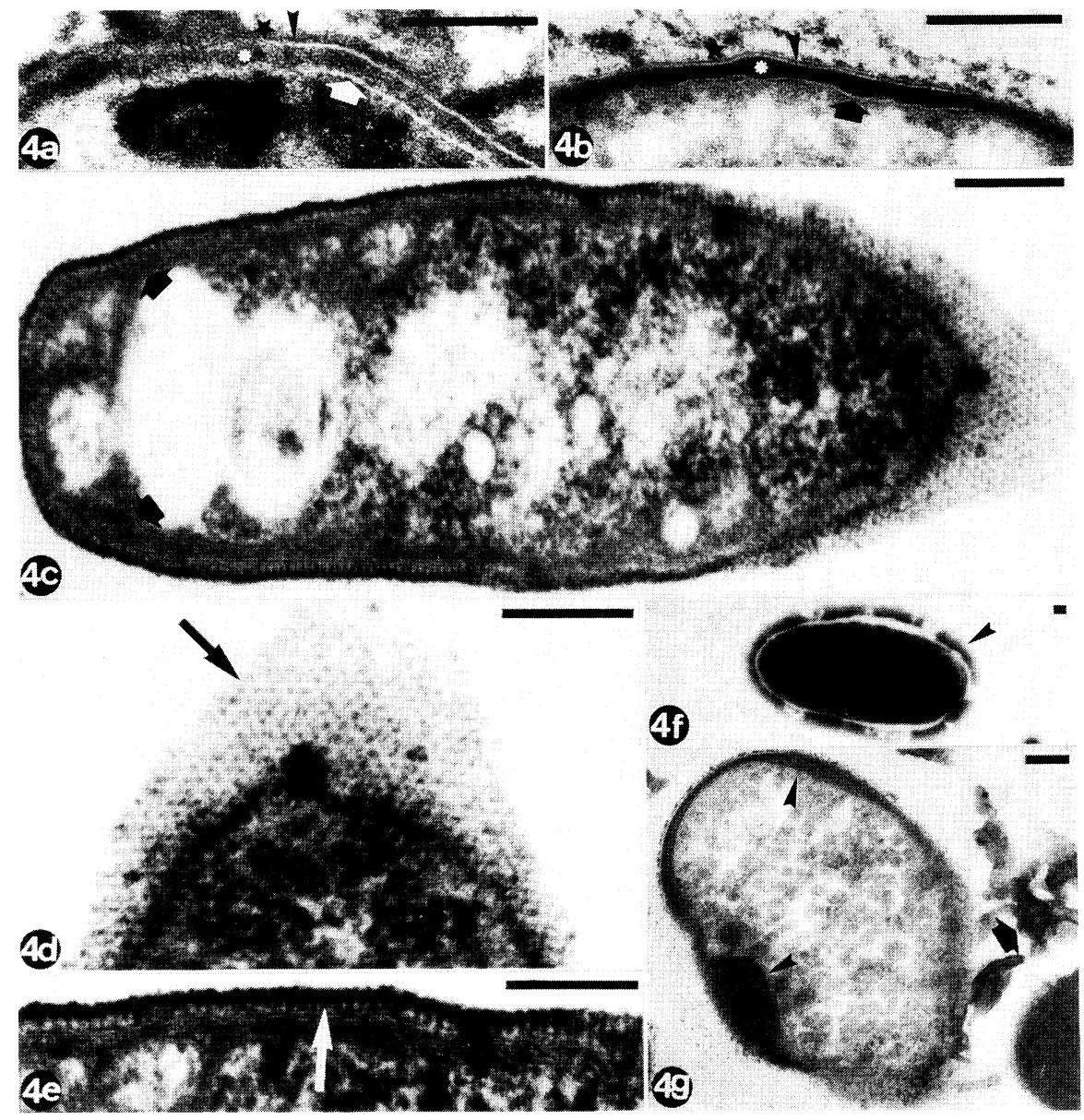

Fig. 4. Gram-negative cell envelope observed by TEM in bacteria collected from PNA2 and cultured in the laboratory in Postgate E medium (a and b), with plasma membrane (arrows), peptidoglycan layer (asterisks), outer membrane (arrowheads) and S layer (stars).

All the components of the cell envelope showed higher contrast after treatment with tannic acid (b). c-e show sessile bacteria after treatment with RR, revealing an S layer with hexagonally arranged molecular subunits (c and d, arrows). Negative staining also revealed the $\mathrm{S}$ layer (f, arrowhead) in sessile bacteria. In certain instances, the periplasmic space was observed to be enlarged ( $g$, arrowheads) and filled with an amorphous and electron-dense material. The bars indicate $0.1 \mu \mathrm{m}$.

b, stars). This multilayered fine structure is characteristic of Gram-negative bacteria. Treatment of the cells with tannic acid induced greater contrast in all the components of the cell envelope (Fig. 4b), especially in the peptidoglycan layer (Fig. 4b, asterisk), which also exhibited a higher density. In preparations with RR, 
sections cut tangentially through the external surface revealed a regular hexagonal array (Fig. 4c, d, arrow) of molecular subunits. Longitudinal sections showed these subunits (Fig. 4e, arrow) organized in parallel arrays, periodically spaced and exhibiting peripheral density. Negative staining also gave a clear image of the $S$ layer (Figs. 2c and 4f, arrowheads). Homogeneously amorphous material (Fig. 4g, arrowheads) with an electron density similar to that of the extracellular matrix (Fig. 4g, arrow) was commonly seen to have accumulated in the periplasmic space of the cell envelope.

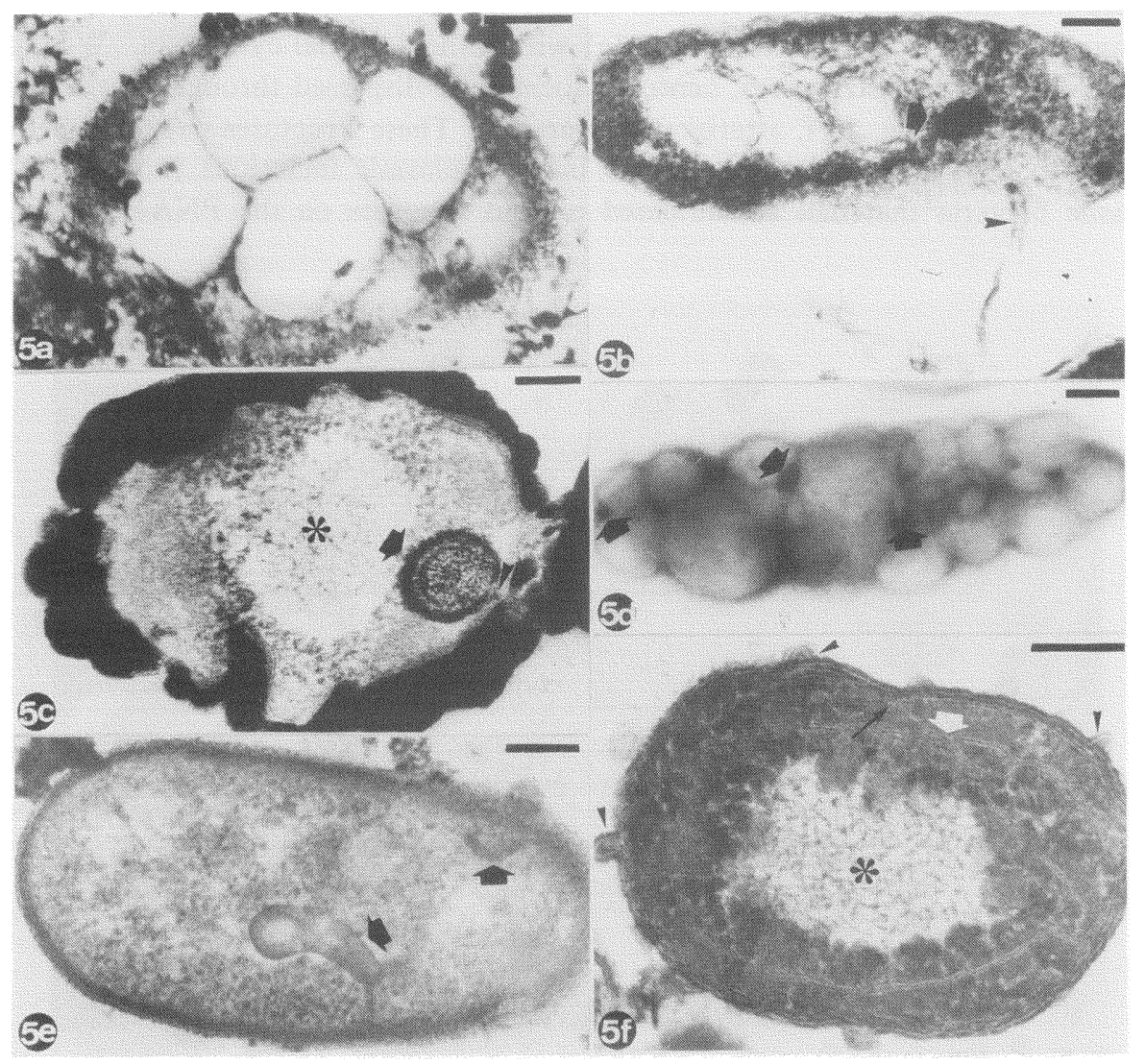

Fig. 5. Electron-lucent ( $a$ and $b$ ) and electron-dense inclusions (b-d, arrows) observed in bacterial cytoplasm, exhibiting a granulous (c, arrow) or homogeneous (b and d, arrows) structure.

A single-layer membrane surrounds some of the electron-transparent inclusions (a and $b$ ). Note the presence of a flagellum (b, arrowhead) and of intracytoplasmatic membranes (arrows) assuming various internal patterns ( $a$ and $b$ ). Intracytoplasmic membranes are also present (e and $f$, large arrows) in a variety of different arrays. Note the presence of "blebs" at the cell surface (f, arrowheads). The bars indicate $0.1 \mu \mathrm{m}$. 


\section{Cell inclusions}

Many different types of cell inclusions, in some cases surrounded by a singlelayer membrane, were observed in the cytoplasm of the bacteria under study. The most commonly observed inclusions appeared as empty and electron transparent structures enclosed by a thin membrane. They were variable in number and size, and resembled gas vacuoles (Fig. 5a,b). Certain electron-dense inclusion bodies (Fig. 5c, arrow) were apparently in contact with the plasma membrane (Fig. 5c, arrowhead). Others, taking the form of granules (Fig. 5b,d, arrows), were frequently found to be distributed as spherical and homogeneous electron-dense inclusions throughout the cytoplasm (Fig. 5d, arrows). Ribosomes appeared as granulous compacted material (Fig. 5e) within the bacterial cytoplasm. We also observed strip-like structures, centrally located or dispersed throughout the cell, with a fibrillar (Fig. 5c, f, asterisks) appearance. These structures were connected either to the plasma membrane or to intracytoplasmic inclusions (not shown). Sessile bacteria that had accumulated in field samplers on the PNA1 platform

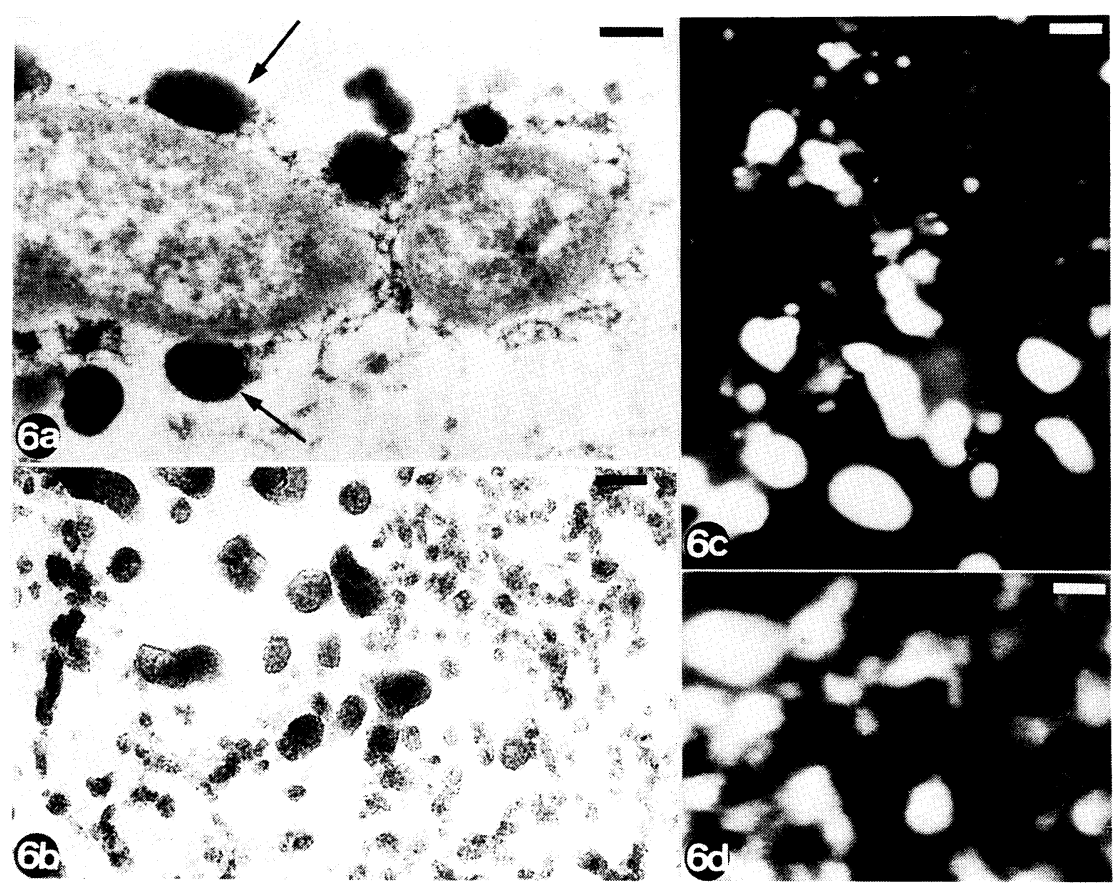

Fig. 6. Conventional TEM of planktonic bacteria cultured in Postgate E medium, showing electron-dense corrosion products associated with the glycocalyx (a, arrows).

ESI analysis of such structures with $\Delta E=0 \mathrm{eV}$ produces an elastic spectroscopic image (b). With $\Delta E=165 \mathrm{eV}$ (c) and $\Delta E=708 \mathrm{eV}$ (d), the inelastic spectroscopic images reveal the presence of sulphur and iron, respectively, in these structures. The bars indicate $0.1 \mu \mathrm{m}$. 
exhibited accentuated intracytoplasmic vacuolization when compared to bacteria cultured in the laboratory. In general, however, the bacteria under study did not display significant intracellular differences that could be related to their source or growth culture medium.

\section{Intracytoplasmic membranes}

A system of intracytoplasmic double-layered membranes was commonly observed either centrally located within the cytoplasm (Fig. 5e, arrows), or running along the periphery of the cell boundary (Figs. $4 \mathrm{c}$ and 5f, large arrows). In certain instances, this type of membrane system was observed projecting inward from the plasma membrane (Fig. 5f, thin arrow).

\section{Corrosion products}

Using conventional TEM, we routinely observed the presence of electrondense structures (Fig. 6a, arrows) in close contact with the bacterial coat, both in sessile and in planktonic cells. To ascertain the chemical nature of these structures, we submitted them to ESI. At the zero-loss mode, the elastic bright-field image (Fig. 6b) when compared to the conventional TEM image (Fig. 6a, arrows) showed the structures in greater detail, with better definition of their granulous formation. Inelastic imaging obtained by setting the spectrometer at $\Delta E=165 \mathrm{eV}$ (Fig. 6c) and $\Delta E=708 \mathrm{eV}$ (Fig. 6d) demonstrated the presence of sulphur and iron, respectively.

\section{DISCUSSION}

Our aim was to characterize the ultrastructure of both planktonic and sessile bacteria causing corrosion in the water injection systems of offshore petroleum platforms off the Atlantic coast of South America. The first characterization performed in the biofilm directly on the platform indicated that we were dealing with a high sulphidogenic population of anaerobic bacteria (F.C.M. Magalhães, unpublished results). Such population was rich in sulphate-reducers, about four times higher than the contamination monitored by Watkins and Costerton in ship-out tanks of an oilfield (28), evaluated as a dangerous condition for development of biocorrosion. Ultrastructural analysis of biofilms formed over in the field samplers revealed that large and diverse microbial communities can adhere to and colonize the interior walls of pipelines, with predominantly Gram-negative bacteria. We did not detect any predominant cell type when comparing different sampling sites.

To further enrich the bacterial population in SRB, we subcultured field samples in SRB-designed media (Postgate C and E media), and to ascertain its presence we monitored their growth using the MPN method (23), observed precipitation of iron sulphide, and tested for production of $\mathrm{H}_{2} \mathrm{~S}$. Since the amount of $\mathrm{H}_{2} \mathrm{~S}$ production was used as an indicator of the SRB levels in cultures, we 
performed a theoretical calculation of the possible reduction of all the inorganic sulphates $\left(\mathrm{Na}_{2} \mathrm{SO}_{4}, \mathrm{MgSO}_{4}\right.$ and $\left.\mathrm{FeSO}_{4}\right)$ present in the Postgate $\mathrm{C}$ medium to $\mathrm{H}_{2} \mathrm{~S}$, characteristic of SRB or alternatively, the possible production of $\mathrm{H}_{2} \mathrm{~S}$ observed from degradation of sulphur amino acids present in the yeast extract, characteristic of sulphide production by other sulphidogenic non-SRB bacteria. Based on the concentrations in the medium formula, if all the inorganic sulphates could be reduced to form $\mathrm{H}_{2} \mathrm{~S}, 2.468 \mathrm{~g} / l$ would be produced. Experimentally, in typical 7 day-old cultures in Postgate $\mathrm{C}$ medium sulphide production yields $1,100 \mathrm{mg} / \mathrm{l}$ of $\mathrm{H}_{2} \mathrm{~S}$, as determined spectrophotometrically (14). On the other hand, the yeast extract would contribute with $0.0037 \mathrm{~g} / l$ to $\mathrm{H}_{2} \mathrm{~S}$ production via proteolysis of its $0.35 \%(\mathrm{w} / \mathrm{w})$ sulphur amino acid content determined by burning in oven at $250^{\circ} \mathrm{F}$ and measuring the infra-red rays, which indicate $\mathrm{CO}_{2}$ production in a LECO SE132 instrument (limit of weight sensitivity $=0.005 \%$ ). So, other sulphidogenic bacteria would be able to produce only less than $0.1 \%$ of the possible $\mathrm{H}_{2} \mathrm{~S}$. Among the possible sulphidogenic bacteria, SRB would contribute to about $99.9 \%$ of the $\mathrm{H}_{2} \mathrm{~S}$ production. Bacteria cultured in the laboratory were also Gram-negative and the analysis of biofilms formed after bacterial adhesion to test surfaces located either on petroleum platforms or in the laboratory, confirms the literature data concerning this kind of bacterial organization found in petroleum industry pipelines $(4,6,13$, $19,21,28)$.

Rather than attempt a taxonomic classification, we analyzed the various morphotypes observed in laboratory cultures using parameters such as morphology, motility and the presence or absence of a flagellum $(11,23)$. Besides the presence of other non sulphur-reducing anaerobes, on the basis of these criteria, a wide range of SRB genera appeared to be present, among them: Desulfomonas (rod), Desulfomicrobium (curved rod), Thermodesulfobacterium (rod), Desulfobulbus (curved rod), Desulfotomaculum (rod, vibrio), Desulfobacterium (rod, vibrio, oval), Desulfovibrio (rod, vibrio, spiral), Desulfobacter (vibrio, oval), Desulfonema (filament), Desulfococcus (round, oval), or Archaeoglobus (round). Bacterial diversity in natural biofilms is known to occur in environments that exhibit similar conditions. Using TEM and SEM, McKinley et al. (19) detected great differences both in terms of the number and the type of bacteria in water samples taken at different times from two oil wells in Los Angeles.

In a wide variety of natural and industrial environments, bacterial cells are found adhering to surfaces, proliferating as microcolonies, producing exopolysaccharidic material and forming an extracellular glycocalyx on their surface (5). Ruthenium red is a specific stain for organic polyanions (17) and thus enables observation of this almost universal bacterial surface component. In our study, routine application of $R R$ revealed the bacterial glycocalyx as a strongly stained material that took the form either of an extensive structure surrounding many cells or of a more limited structure enclosing individual bacteria. The exopolysaccharide layer covering the biofilm creates a microenvironment that can protect bacteria from bacteriophages, antibiotics, biocides and surfactant agents (5). In another 
study, we observed that in SRB-enriched biofilms the morphology of the bacterial glycocalyx and of the associated extracellular matrix varied, depending on the nature of the bacterial population under study (planktonic or sessile) and on the growth medium used (9).

The peptidoglycan layer of the bacterial cell envelope stained strongly with tannic acid. The basic arrangement of the inner and outer membranes was also more clearly visible after treatment with tannic acid. The higher contrast, and therefore improved visibility, induced by this agent results from its propensity to combine with basic proteins or other polyvalent molecules on the cell surface (27). In certain parts of the cell envelope we detected enlarged periplasmic spaces. Recently, Mody et al. (20) reported similar findings relating the compartmentalization of the periplasmic space of Gram-negative bacteria Cowpea rhizobia with the process of polysaccharide excretion. The use of RR, as described by Austin et al. (2), helped us to observe the $S$ layer in bacteria collected from field samplers or grown in mixed cultures, both in planktonic and sessile organisms. Molecular subunits were observed to be organized in a periodic hexagonal array. Negative staining of SRB suspensions also revealed the S layer. The presence of an S layer in SRB is not well documented and this is the first description of such an arrangement in the bacteria collected from a water injection system in the petroleum industry. Zellner et al. (29) failed to detect an S layer when they carried out negative staining, but it should be noted that their study focused on an isolated culture of Desulfovibrio simplex. The $\mathrm{S}$ layer, which may develop as a consequence of interactions with environmental factors that threaten bacterial life (25) is usually absent from pure cultures.

The presence of intracytoplasmic membranes, almost invariably associated with the plasma membrane, may be related to an increased need for available areas in which the intense metabolic activity characteristic of SRB can take place, given some reactions are conducted by enzymes located in membranes (22). Using transmission electron microscopy, it was shown that Desulfobacter postgatei posseses an outer membrane, a cytoplasmic membrane and some seemingly stacked membranes within the cytoplasm (23). In addition, three different types of hydrogenases, important enzymes in SRB ecology (22), have been found in the periplasm, in the membranes and in the cytoplasm of Desulfovibrio desulfuricans (24) and three nickel-containing membrane-bound hydrogenases have been detected in Desulfovibrio vulgaris (16). In Desulfovibrio gigas, a number of enzymes (menaquinone; b-type cytochrome; fumarate reductase) have been located in the membrane fraction, while others (desulfoviridin, adenylsulphate reductase, ferredoxin) have been found in a number of species of Desulfovibrio grown in very different cultural conditions, demonstrating a degree of biochemical compartmentalization in these bacteria (23).

We observed a great diversity of intracytoplasmic inclusions in the course of our electron microscopic analysis of bacteria. However, only a more detailed molecular and biochemical characterization of these inclusions will make it possible 
to ascertain their function and real importance in the bacterial metabolism.

In the course of our study, we detected the presence of corrosion products, using both X-ray energy dispersive micro-analysis (not shown) and ESI techniques. ESI detected the presence of iron sulphide, a characteristic product of SRB, with sulphur (Fig. 6c) and iron (Fig. 6d) both being observable as electron-dense structures (Fig. 6a, arrows) associated with the extracellular matrix, in planktonic and sessile bacteria. It has been suggested that one of the mechanisms causing biocorrosion may involve the production of corrosive iron sulphides through a reaction of ferrous metals with the hydrogen sulphide released during bacterial metabolism (15).

In conclusion, the bacteria growing in the pipelines of marine injection systems operated by the Brazilian petroleum company were found to be numerous, but also to exhibit diverse morphologies and interior features. Even when grown in the laboratory with media designed to promote SRB growth, they appeared as mixed populations. We believe that our ultrastructural characterization of these bacteria, besides contributing to the general body of knowledge about the processes of biocorrosion, offers a useful description of corrosive sulphidogenic biofilms rich in SRB located especially off the coast of Brazil.

We are grateful to Nilda L. da Mota, Amalia Furtado, Riacrdo C. Moni, Roger M. Galdino, and Genilto Vieira for technical and photographic assistance and to Luiz E. V. Aguiar for helpful discussions.

This study was supported by PETROBRAS and FIOCRUZ.

\section{REFERENCES}

1) Araújo-Jorge, T. C., Coutinho, C. M. L. M., and Aguiar, L. E. V., Sulphate-reducing bacteria associated with biocorrosion: A review. Mem. Inst. Oswaldo Cruz, 87, 329-337 (1992).

2) Austin, J. W., Stewart, M., and Murray, R. G. E., Structural and chemical characterization of the S layer of a Pseudomonas-like bacterium. J. Bacteriol., 171, 808-817 (1990).

3) Bergey, D. H., Krieg, N. R., Holt, J. G., Murray, R. G. E., Brenner, D. J., Bryant, M. P., Holt, J. G., Moulder, J. W., Pfenning, N., Sneath, P. H. A., and Staley, J. T., Bergey's Manual of Systematic Bacteriology, The Williams \& Wilkins, Baltimore/London (1984), p. 5-48.

4) Characklis, W. G. and Cooksey, K. E., Biofilms and microbial fouling. Adv. Appl. Microbiol., 29, 93-133 (1983).

5) Costerton, J. W., Cheng, K.-J., Geesey, G. G., Ladd, T. I., Nickel, J. C., Dasgupta, M., and Marrie, T. J., Bacterial biofilms in nature and disease. Annu. Rev. Microbiol., 41, 435-464 (1987).

6) Costerton, J. W. and Lappin-Scott, H. M., Behavior of bacteria in biofilms. ASM News, 55, 650654 (1989).

7) Costerton, J. W., Marrie, T. J., and Cheng, K.-J., Phenomena of Bacterial Adhesion, ed. by Savage, D. C. and Fletcher, M., Plenum Publishing Co., New York (1985), p. 3-43.

8) Coutinho, C. M. L. M., Magalhães, F. C., and Araújo-Jorge, T. C., Scanning electron microscope study of biofilm formation at different flow rates over metal surfaces using sulphate-reducing bacteria. Biofouling, 7, 19-27 (1993).

9) Coutinho, C. M. L. M., Magalhães, F. C., and Araújo-Jorge, T. C., Morphology of the surface coat and extracellular matrix of sulphidogenic biofilms enriched in sulphate-reducing bacteria 
involved in biocorrosion processes in the offshore oil extraction industry off Brazil's coast. J. Gen. Appl. Microbiol., 40, 271-276 (1994).

10) Gaylarde, C. C. and Videla, H. A., Localized corrosion induced by a marine vibrio. Int. Biodeterior., 23, 91-104 (1987).

11) Gibson, G. R., Physiology and ecology of sulphate-reducing bacteria: A review. J. Appl. Bacteriol., 69, 769-797 (1990).

12) Hamilton, W. A., Sulphate-reducing bacteria and the offshore oil industry. Trends Biotechnol., 1, 36-40 (1983).

13) Hamilton, W. A., Sulphate-reducing bacteria and anaerobic corrosion. Annu. Rev. Microbiol., 39, 195-217 (1985).

14) Jacobs, A. V., Braverman, P., and Hochener, J. C., Ultramicrodeterioration of sulphides in air. Anal. Chem., 29, 1349 (1957).

15) King, R. A. and Miller, J. D. A., An outline of 150 man-years of microbial corrosion studies at UMIST. Corrosion 87, paper 368, NACE, San Francisco (1987), p. 368/1-368/14.

16) Lissolo, T., Choi, E. S., Legall, J., and Peck, H. D., Jr., The presence of multiple intrinsic membrane nickel-containing hydrogenases in Desulfovibrio vulgaris (Hildenborough). Biochem. Biophys. Res. Commun., 139, 701-708 (1986).

17) Luft, J. H., Ruthenium red and violet. Chemistry, purification, methods of use for electron microscopy and mechanisms of action. Anat. Rec., 171, 347-368 (1971).

18) McCoy, W. F., Bryers, J. D., Robbins, J., and Costerton, J. W., Observations of fouling biofilm formation. Can. J. Microbiol., 27, 910-917 (1981).

19) McKinley, V. L., Costerton, J. W., and White, D. C., Microbial biomass, activity and community structure of water and particulates retrieved by backflow from a waterflood injection well. Appl. Environ. Microbiol., 54, 1383-1393 (1988).

20) Mody, B., Mody, R., and Modi, V., Freeze-etch study of the cell envelope of Cowpea rhizobia: Compartmentalization of the periplasmic space in relation to polysaccharide excretion. Can. J. Microbiol., 36, 373-383 (1990).

21) Obuekwe, O. C., Westlake, D. S., Cook, F. D., and Costerton, J. W., Surface changes in mild steel coupons from the action of corrosion-causing bacteria. Appl. Environ. Microbiol., 41, 766-774 (1981).

22) Pankhania, I. P., Hydrogen metabolism in sulphate-reducing bacteria and its role in anaerobic corrosion. Biofouling, 1, 27-47 (1988).

23) Postgate, J. R., The Sulphate-Reducing Bacteria, Cambridge University Press, Cambridge (1984), p. 9-55.

24) Rieder, R., Cammack, R., and Hall, D. O., Purification and properties of the soluble hydrogenase from Desulfovibrio desulfuricans (strain Norway 4). Eur. J. Biochem., 145, 637-643 (1984).

25) Sleytr, U. B. and Messner, P., Crystalline surface layers on bacteria. Annu. Rev. Microbiol., 37, 311-339 (1983).

26) Videla, H. A., Metal Dissolution/Redox in Biofilms, ed. by Characklis, W. G. and Wilderer, P. A., John Wiley \& Sons Ltd., New York (1989), p. 301-320.

27) Wagner, R. C., The effect of tannic acid on electron images of capillary endothelial cell membranes. J. Ultrastruct. Res., 57, 132-139 (1976).

28) Watkins, L. and Costerton, J. W., Growth and biocide resistance of bacterial biofilms in industrial systems. Chem. Times \& Trends, 33, 35-40 (1984).

29) Zellner, G., Messner, P., Kneifel, H., and Winter, J., Desulfovibrio simplex spec. nov., a new sulfate-reducing bacterium from a sour whey digester. Arch. Microbiol., 152, 329-334 (1989). 